(2) Open Access Full Text Article

LETTER

\title{
Improving medical students' participation in research
}

This article was published in the following Dove Press journal:

Advances in Medical Education and Practice

\section{Rahul Menon \\ Vishnou Mourougavelou Arjun Menon \\ Faculty of Medicine, Imperial College London, London, UK}

Correspondence: Vishnou

Mourougavelou

I5 Somerville Road, Romford RM6 5BD,

Essex, UK

Tel +44794736 I320

Emailvm713@ic.ac.uk

\section{Dear editor}

We read with great interest the review by Siddaiah-Subramanya et $\mathrm{al}^{1}$ regarding the difficulty for medical students to participate in research, in developing countries. From our own experience as medical students, we agree that organizational factors, adequacy of knowledge, and variability in "attitudes" may all contribute to difficulty in participating in research. Nevertheless, we propose that the introduction of research projects, which may be part of an intercalated degree, could help improve medical students' involvement in research.

The authors have suggested that inadequate knowledge of research principles is one of the main barriers for students participating in research. One strategy to encourage research is to provide medical students research fellowships in the first or second year of medical school. ${ }^{2}$ Further to this, many UK universities are now advocating the integration of an intercalated degree as a part of their undergraduate curriculum. ${ }^{3}$ During this research-intensive year, students are taught how to adequately appraise scientific literature. ${ }^{3}$ The program also develops a structured approach to undertaking research as well as promoting deep and strategic learning. ${ }^{3}$

Medical institutions are eager to promote research in order to prepare students for a career in evidence-based medicine. ${ }^{4}$ Studies have identified other reasons to engage in research such as the ability to appraise clinical evidence and the development of analytical skills which are required in medical practice. ${ }^{1,4}$

There are also several significant barriers to research, which affect Asia specifically. These include a lack of funds, a "brain drain" of health care professionals, and no regional medical education journal. ${ }^{5}$ Whilst there is not a simple solution to solve the underrepresentation of medical students in research, strategies such as holding more student-led conferences, promoting student journals, and holding research workshops will help in achieving this goal. ${ }^{4}$

A grounding in the principles of scientific research is vital for all medical students regardless of whether they want to pursue a career in academia or not. ${ }^{4} \mathrm{We}$ agree with the authors regarding the discrepancies in conducting research between developed and developing countries. However, there is merit in acknowledging that dedicated research projects could be the answer to equip medical students with scientific rigor.

\section{Disclosure}

The authors report no conflicts of interest in this communication. 


\section{References}

1. Siddaiah-Subramanya M, Singh H, Tiang KW. Research during medical school: is it particularly difficult in developing countries compared to developed countries? Adv Med Educ Pract. 2017;8:771-776.

2. Solomon SS, Tom SC, Pichert J, Wasserman D, Powers AC. Impact of medical student research in the development of physician-scientists. $J$ Investig Med. 2003;51(3):149-156.
3. McManus IC, Richards P, Winder BC. Intercalated degrees, learning styles, and career preferences: prospective longitudinal study of UK medical students. BMJ. 1999;319(7209):542-546.

4. Aslam F, Shakir M, Qayyum MA. Why medical students are crucial to the future of research in South Asia. PLoS Med. 2005;2(11):e322.

5. Majumder MA. Issues and priorities of medical education research in Asia. Ann Acad Med Singapore. 2004;33(2):257-263. 


\section{Authors' reply}

Manjunath Siddaiah-Subramanya ${ }^{1,2}$

Harveen Singh ${ }^{3}$

Kor Woi Tiang ${ }^{1,2}$

'Department of Surgery, Logan Hospital, Meadowbrook, ${ }^{2}$ Department of Medicine, Griffith University, Nathan, ${ }^{3}$ Department of Gastroenterology, Lady Cilento Children's Hospital, Brisbane, QLD, Australia

\author{
Correspondence: Manjunath Siddaiah-Subramanya \\ Department of Surgery, Logan Hospital, Corner Armstrong Road and \\ Loganlea Road, Meadowbrook, QLD 4I3I, Australia \\ Tel +6I 4 477I 9975 \\ Email manjunathbss9@yahoo.com
}

\section{Dear editor}

We would like to thank Menon et al for the letter in response to our article. ${ }^{1}$ We note that an overarching theme in the letter is the situation in countries where research at medical school could be improved. In the letter, Menon et al have brought out a couple of important issues: one is that the problem is multifactorial, and the other is the fact that opportunities and encouragement need to be provided to the students so that they could get more involved in research. Intercalated degrees are becoming more popular, and they are one of the ways to improve the situation. They allow the medical students to dedicate an entire year or 2 to learn and participate in quality research. As mentioned by Menon et al, they have already been accepted in the UK medical education system. Here in Australia, various medical universities have adopted this system, and the medical students get an MD instead of an MBBS at the end. Furthermore, some are even encouraged to complete a $\mathrm{PhD}$ during the research break prior to continuing with the rest of the medical degree.

On the note of "brain drain", it is indeed a sad state in some underprivileged countries where potentially a lot of talent is wasted due to, mainly, lack of opportunities. Additionally, the priorities of most students from these regions are different, and many cannot afford to spend extra years in medical schools instead of earning for their families.

\section{Disclosure}

The authors report no conflicts of interest in this communication.

\section{Reference}

1. Siddaiah-Subramanya M, Singh H, Tiang KW. Research during medical school: is it particularly difficult in developing countries compared to developed countries? Adv Med Educ Pract. 2017;8:771-776.

Dove Medical Press encourages responsible, free and frank academic debate. The content of the Advances in Medical Education and Practice 'letters to the editor' section does not necessarily represent the views of Dove Medical Press, its officers, agents, employees, related entities or the Advances in Medical Education and Practice editors. While all reasonable steps have been taken to confirm the content of each letter, Dove Medical Press accepts no liability in respect of the content of any letter, nor is it responsible for the content and accuracy of any letter to the editor.

\section{Publish your work in this journal}

Advances in Medical Education and Practice is an international, peerreviewed, open access journal that aims to present and publish research on Medical Education covering medical, dental, nursing and allied health care professional education. The journal covers undergraduate education, postgraduate training and continuing medical education including emerging trends and innovative models linking education, research, and health care services. The manuscript management system is completely online and includes a very quick and fair peer-review system. Visit http://www.dovepress.com/testimonials.php to read real quotes from published authors. 